\section{Chlamydia trachomatis infection in young pregnant women in Southern Brazil: a cross-sectional study}

\section{Infecção por Chlamydia trachomatis em gestantes jovens no Sul do Brasil: um estudo transversal}

\author{
Infección por Chlamydia trachomatis en gestantes \\ jóvenes en el sur de Brasil: un estudio transversal
}

Mariângela Freitas da Silveira 1

Iândora Krolow Timm Sclowitz 1

Ludmila Gonçalves Entiauspe 2

Marilia Arndt Mesenburg 2

Dulce Stauffert 1

Guilherme Lucas de Oliveira Bicca 1

Carine Pieniz 1

Adriane Brod Manta 1

doi: 10.1590/0102-311X00067415

\begin{abstract}
This study estimated the prevalence of Chlamydia trachomatis infection during pregnancy in a sample of women up to 29 years of age in the city of Pelotas, Rio Grande do Sul State, Brazil, and investigated socio-demographic risk factors such as maternal age, marital status, maternal schooling, and family income. C. trachomatis infection was diagnosed with PCR using BD ProbeTecTM CT/GC Amplified DNA Assay. Socio-demographic, behavioral, and reproductive data were collected using structured questionnaires. All collections were performed by previously trained medical students. The study included a stratified probabilistic sample from four maternity hospitals in the city. The sample included 562 pregnant women, and prevalence of $\mathrm{C}$. trachomatis infection was 12.3\% (95\%CI: 9.6-15.0). No significant association was identified between C. trachomatis infection and any of the target variables, including obstetric outcomes such as history of preterm delivery. Our findings in terms of low treatment adherence, only 43\% of the women and $9.7 \%$ of partners, associated with high $\mathrm{C}$. trachomatis prevalence, reinforce the need to implement routine screening for $\mathrm{C}$. trachomatis during prenatal care. The attempt to diagnose and treat this infection after delivery, as in this study, limits the possibility of success.
\end{abstract}

Chlamydia; Reproductive Tract Infections; Premature Birth;

Sexually Transmitted Diseases

\section{Correspondence}

M. A. Mesenburg

Rua Marechal Deodoro 1160, Pelotas, RS 96020-220, Brasil.

mariliaepi@gmail.com

1 Faculdade de Medicina, Universidade Federal de Pelotas, Pelotas, Brasil.

2 Programa de Pós-graduação em Epidemiologia, Universidade Federal de Pelotas, Pelotas, Brasil. 


\section{Introduction}

Chlamydia trachomatis is the most prevalent bacterial sexually transmitted infection (STI) and is a common cause of urethritis and cervicitis, leaving such sequelae as pelvic inflammatory disease, ectopic pregnancy, and tubal factor infertility 1 . Approximately $20 \%$ of women with lower genital tract infection develop pelvic inflammatory disease, $4 \%$ chronic pelvic pain, $3 \%$ infertility, and $2 \%$ adverse pregnancy outcomes 1 .

In Brazil, studies with different populations and methodologies have reported high prevalence of C. trachomatis infection. Research in a prenatal clinic with 122 pregnant women in São Paulo found $C$. trachomatis prevalence of $9 \% 2$. A study of adolescents with high-risk sexual behaviors attending the Family Health Program in Vitória (Espírito Santo State) reported C. trachomatis prevalence of 8.9\% 3. A national cross-sectional study of postpartum women aged 15 to 24 years and attending public hospitals in 2009 tested 2,071 women using molecular biology (Amplicor CT/NG, Roche, Berlin, Germany) and found C. trachomatis prevalence of 9.8\% (95\%CI: 8.5-11.1). Factors associated with C. trachomatis infection included age $<19$ years, first intercourse $<15$ years, more than one lifetime partner, no Pap smear in the previous 12 months, and Neisseria gonorrhoeae infection 4 . A study of pregnant women in the United States $(\mathrm{N}=2,127)$ found $C$. trachomatis prevalence of $4.7 \%$, also suggesting increased risk in women who were young, single, black, smokers, and infected with $N$. gonorrhoeae, with young age being the main predictor 5 .

The Brazilian National STD-AIDS Program, under the Brazilian Ministry of Health, has published a sexually trasnmited disease (STD) guidelines recommending a flowchart for the syndromic approach to vaginal discharge and cervicitis syndromes, with well-defined risk criteria for cervicitis 6 . A national study included 472 sexually active female adolescents 15 to 19 years of age, tested with polymerase chain reaction (PCR) for $N$. gonorrhoeae and C. trachomatis, and the results were compared with risk score performance and presence of clinical signs of cervicitis. The study showed prevalence rates for $C$. trachomatis and $N$. gonorrhoeae of $14.5 \%$ and $2.1 \%$, respectively. The risk score had a specificity of $31.9 \%$ (95\%CI: 21.2-44.2) and positive predictive value (PPV) of 20.8\% (95\%CI: 13.5-29.7). Presence of friability of the cervix was the clinical sign with the best performance, with a sensitivity of $43.5 \%$, specificity of $81 \%$, and PPV of $30.6 \%$. The authors concluded that prevalence of C. trachomatis infection was high in this population, and that the syndromic approach is inadequate for screening, so that other screening strategies are needed in this population 7.

Several Brazilian studies have confirmed a trend to increasing prematurity rates 8 . Although part of this increase has been attributed to the huge increase in cesarean deliveries, a similar trend has also been observed in vaginal deliveries 9 . A review of Brazilian population-based studies indicated a significant upward trend in prematurity since the 1990s 10.

Several studies have shown an association between genital infections and both prematurity and low birth weight $(<2,500 \mathrm{~g})$, with infection causing up to $40 \%$ of spontaneous preterm births 11 . The odds ratio for prematurity and abnormal genital flora is detected between 26 and 32 weeks gestational age and ranges from 1.4 to 2, whereas in the case of abnormal genital flora from seven to 16 weeks gestational age, the odds ratio varies from 5 to 7.5 12. Evidence suggests that treatment before 20 weeks gestational age can reduce the risk of preterm birth 13 .

Genital tract infections are common findings in gynecological and prenatal clinics. Meanwhile, data suggest that the occurrence of preterm birth is increasing in Brazil, leading to increasing use of tertiary health facilities such as neonatal intensive care units (NICU) and thus to rising costs for the Brazilian Unified National Health System (SUS).

The U.S. Preventive Services Task Force (USPSTF) recommends (with level of evidence A) that pregnant women at increased risk of STDs undergo screening for C. trachomatis and N. gonorrhoeae, with age less than 25 years considered a non-modifiable risk factor 14 .

The asymptomatic nature of $C$. trachomatis makes screening essential for controlling the infection. Sweden has implemented policies since the 1980s to reduce the prevalence of infection, experiencing a decline in C. trachomatis infection rates and complications 15. Several other countries, including the United Kingdom, France, Netherlands, Finland, Scotland, and Australia, have introduced measures to reduce the prevalence of this infection 14,15,16,17,18,19. In Brazil, although the new official clinical protocol for treatment of sexually transmitted infections includes the recommendation for C. trachomatis 
screening 20 , when available, for pregnant women younger than 25 years old, this test is not covered by the SUS and is not part of routine prenatal care recommended by the Brazilian Ministry of Health 21 .

Given the high prevalence of genital infections and premature births in Brazil, studies aimed at elucidating this subject can contribute greatly to public health. This study aimed to investigate the prevalence of genital C. trachomatis in pregnant women at the time of their admission for childbirth at the participating study hospitals, as well as to study socio-demographic risk factors for this infection.

\section{Methods}

This was a cross-sectional population-based study of pregnant women in Pelotas, a city with approximately 328,000 inhabitants located in the far South of Brazil. The study included pregnant women 15 to 29 years of age admitted during labor in all maternity wards in the municipality from December 2011 to May 2013. Pregnant women who reported having used antibiotics in the previous month were excluded from the study. Sample size calculation to estimate the prevalence of $C$. trachomatis infection was performed using the following parameters: prevalence of 10\% 4, margin of error of three percentage points, and $95 \%$ confidence level. A sample of 570 women was needed.

Pregnant women were selected to participate in the study through stratified sampling in proportion to the percentage of obstetric care provided in each maternity hospital. Within each hospital, a predefined number of pregnant women were invited to participate in the study. This process aimed to ensure the sample's representativeness. Within each hospital, a convenience sampling procedure was used. Mothers who were in the delivery ward when the team of interviewers visited were invited to participate.

The main outcome was prevalence of C. trachomatis. Pregnant women with a positive test were considered infected and therefore were part of the study numerator. The independent variables were the following: hospital of birth, maternal age (15-17, 18-24, and 25-29), education in years (1-4, 5-8, 9 or more), marital status (married/with live-in partner, single, widowed, separated/divorced) later recoded as a dichotomous variable (with-partner versus unmarried), family income in national minimum wages (up to 1, 1-3, 4-5, 6 or more), number of prenatal care visits (up to 3, 4 or more), number of previous pregnancies (0, 1, 2 or more), history of preterm birth (yes, no), prenatal care in the SUS (yes, no), illegal drug use (yes, no), smoking during the pregnancy (yes, no), alcohol use in the previous month (yes, no), alcohol use in the previous week (yes, no), urinary tract infection during the pregnancy (yes, no), mode of delivery (cesarean, vaginal), premature rupture of membranes (yes, no), preterm delivery before 32 weeks gestational age (yes, no), and preterm delivery before 37 weeks gestational age (yes, no).

The status of $C$. trachomatis infection was obtained by polymerase chain reaction (PCR) using the BD ProbeTecTM CT/GC Amplified DNA Assay Collection Kit for Endocervical Specimens (Franklin Lakes, U.S.A.), conducted on material collected by vaginal swab. Socio-demographic, behavioral, and reproductive data were collected through previously tested structured questionnaires administered in individual interviews. Information on premature rupture of membranes and gestational age at delivery were obtained from the medical staff. Collection of biological material and interviews were conducted by previously trained medical students. The samples were transported to the laboratory in appropriate containers with controlled temperature $\left(8-15^{\circ} \mathrm{C}\right)$ and stored at $-20^{\circ} \mathrm{C}$ in a freezer until processing.

Data were double-entered in Epidata 3.1 (Epidata Assoc., Odense, Denmark), and SPSS-20 (SPSS Inc., Chicago, U.S.A.) was used for statistical analyses.

Descriptive analyses of the sample's characteristics, including means, standard deviations, and distribution among defined groups, were initially performed. Exploratory analyses were used regarding possible risk factors for this infection, with bivariate analyses performed between the outcome C. trachomatis infection and each of the independent variables. Finally, multivariate logistic regression analysis using backward elimination was performed.

The project was approved by the Institutional Review Board of the School of Medicine, Federal University of Pelotas, under case review OF 69/10. All respondents provided written informed consent, the test results were provided to patients, and treatment, when necessary, was provided free of cost for both the women and their partners. 


\section{Results}

The final sample consisted of 562 pregnant women. Mean age was 22.4 years $(\mathrm{SD}=4.0) ; 54 \%$ were 18 to 24 years of age, 53\% had nine or more years of education, $62 \%$ reported family incomes between 1 and 3 times the minimum wage, and $84 \%$ lived with husband or partner. Regarding behavioral variables, $16 \%$ smoked during pregnancy, and $16 \%$ reported having consumed alcohol in the previous month and $4 \%$ in the previous week. Illegal drug use was reported by $5 \%$ of participants.

In relation to prenatal care variables, attending more than four consultations was highly common (86\%), as well as receiving such care in the SUS (84\%). In terms of reproductive history, most mothers $(52 \%)$ were primiparous, and prevalence of previous preterm delivery was 19\% among those with a previous child. With regard to the present pregnancy and childbirth, urinary tract infections were reported by $42.4 \%$, about $61 \%$ of participants gave birth via cesarean section, and premature rupture of membranes occurred in $14 \%$ of cases. Prevalence of birth before 32 weeks gestational age was $2 \%$ and before 37 weeks of gestation was $21 \%$. Table 1 shows the sample's characteristics.

Prevalence of C. trachomatis was $12.3 \%$ (95\%CI: 9.6-15.0). Among women with a positive PCR for C. trachomatis, $43 \%$ underwent treatment according to study protocol. The percentage of treatment of partners was 9.7\% (data not shown in table).

Table 2 shows the results of crude analysis comparing C. trachomatis infection and independent variables. The highest odds ratios were obtained for the association between $C$. trachomatis and no previous history of preterm delivery ( $\mathrm{OR}=3.45$; $95 \% \mathrm{CI}$ : $0.79-14.99)$, prenatal care in the SUS ( $\mathrm{OR}=1.72$; $95 \% \mathrm{CI}$ : $0.76-3.90)$, and young maternal age with $\mathrm{OR}=1.75$ (95\%CI: 0.97-3.16) for the 18-24-year category and $\mathrm{OR}=1.72$ (95\%CI: 0.73-4.08) for < 18 years, compared to women 25-29 years of age. None of the study variables reached statistical significance $(\mathrm{p}<0.05)$ in association with $C$. trachomatis infection in either the crude or adjusted analysis.

\section{Discussion}

Prevalence of C. trachomatis infection was 12.3\% (95\%CI: 9.6-15.0). In women aged 15-24 years, the prevalence increased to $14.2 \%$ (95\%CI: 10.6-17.8), well above the 9.8\% (95\%CI: 8.5-11.1) 4 reported in a national sample of pregnant women in this age bracket. Our result is twice the prevalence of $6.9 \%$ (95\%CI: 3.6-10.2) reported by the national study when the sample was limited to Southern Brazil, where our sample was recruited. Possible reasons for the higher prevalence in our sample when compared to the national study is the fact that Pelotas is economically disadvantaged compared to most of Brazil's Southern region 22.

Our analyses of risk factors, although exploratory, failed to detect any socioeconomic, demographic, behavioral, or childbirth-related variables significantly associated with C. trachomatis infection. Because our study primarily aimed to measure prevalence, the statistical power for detecting risk factors was low. The lowest p-value (0.10) for C. trachomatis infection was for absence of previous history of preterm delivery. In our sample, maternal age below 25 years was associated with a non-significant $70 \%$ increase in prevalence, consistent with the national study and other studies that found higher prevalence in adolescents 5 . In our opinion, the importance of our findings (although not significant) is that they were also in the expected direction for low education, smoking, alcohol use, and lack of a partner as risk factors for $C$. trachomatis infection. Furthermore, as far as we know this was the first population-based study in Brazil that included women who attended private prenatal care. The fact that women receiving prenatal case in the public sector, where $C$. trachomatis testing is not performed, appear to have higher prevalence than those attending private facilities, where screening is more frequent, should be a subject of further studies.

With regard to age, countries that adopt routine $C$. trachomatis screening limit the procedure to women less than 25 years of age $23,24,25$, as screening older women is not cost-effective 26 . However, our study found a high prevalence of $C$. trachomatis infection in this older age group (8.7\%), suggesting that countries such as Brazil where routine screening is not deployed should consider expanding the age range.

Although several attempts were made to contact pregnant women who tested positive using the phone number provided at recruitment, we obtained low compliance: $43 \%$ of the women and $9.7 \%$ of 
Table 1

Characteristics of a sample ( $N=562$ ) of pregnant women 15-29 years of age admitted for childbirth in maternity hospitals. Pelotas, Rio Grande do Sul State, Brazil.

\begin{tabular}{|c|c|c|}
\hline Variable & $n *$ & $\%$ \\
\hline \multicolumn{3}{|l|}{ Hospital delivery } \\
\hline 1 & 163 & 29.9 \\
\hline 2 & 128 & 22.8 \\
\hline 3 & 35 & 6.2 \\
\hline 4 & 236 & 42.0 \\
\hline \multicolumn{3}{|l|}{ Maternal age (years) } \\
\hline$<17$ & 64 & 11.4 \\
\hline $18-24$ & 302 & 53.7 \\
\hline $25-29$ & 196 & 34.9 \\
\hline \multicolumn{3}{|l|}{ Maternal education (years) } \\
\hline $1-4$ & 39 & 6.9 \\
\hline $5-8$ & 226 & 40.2 \\
\hline$\geq 9$ & 297 & 52.8 \\
\hline \multicolumn{3}{|c|}{ Family income (minimum wage) } \\
\hline$<1$ & 89 & 15.8 \\
\hline $1-3$ & 346 & 61.6 \\
\hline $4-5$ & 71 & 12.6 \\
\hline$>5$ & 56 & 10.0 \\
\hline \multicolumn{3}{|l|}{ Marital status } \\
\hline Married/With partner & 469 & 83.5 \\
\hline Unmarried & 93 & 16.5 \\
\hline \multicolumn{3}{|c|}{ Smoking during index pregnancy } \\
\hline No & 475 & 84.5 \\
\hline Yes & 87 & 15.5 \\
\hline \multicolumn{3}{|c|}{ Alcohol use in previous month } \\
\hline No & 474 & 84.5 \\
\hline Yes & 87 & 15.5 \\
\hline \multicolumn{3}{|l|}{ History of preterm birth } \\
\hline No & 218 & 81.3 \\
\hline Yes & 50 & 18.7 \\
\hline \multicolumn{3}{|c|}{ Number of prenatal care visits } \\
\hline$\leq 3$ & 76 & 13.5 \\
\hline$\geq 4$ & 484 & 86.1 \\
\hline \multicolumn{3}{|l|}{ Antenatal care at SUS } \\
\hline No & 90 & 16.4 \\
\hline Yes & 458 & 83.6 \\
\hline
\end{tabular}

SUS: Brazilian Unified National Health System.

* Some totals differed due to missing data.

the partners. This is despite the fact that treatment was free of cost and that various treatment access options were offered to patients and partners.

Our findings on low compliance, coupled with the high prevalence of C. trachomatis infection, reinforce the need to implement routine C. trachomatis screening during prenatal care, especially among women under 25 years. 


\section{Table 2}

Unadjusted associations between Chlamydia trachomatis infection and socio-demographic, behavioral, and reproductive variables related to childbirth in pregnant women 15-29 years old admitted for childbirth in maternity hospitals. Pelotas, Rio Grande do Sul, State, Brazil.

\begin{tabular}{|c|c|c|c|}
\hline Variable & $\begin{array}{c}\text { C. trachomatis prevalence } \\
\mathrm{n}(\%)\end{array}$ & Crude OR $(95 \% \mathrm{Cl})$ & p-value * \\
\hline Maternal age (years) & & & 0.17 \\
\hline$<17$ & $9(14.1)$ & $1.72(0.73-4.08)$ & \\
\hline $18-24$ & $43(14.2)$ & $1.75(0.97-3.16)$ & \\
\hline $25-29$ & $17(8.7)$ & 1.00 & \\
\hline Maternal education (years) & & & 0.50 \\
\hline $1-4$ & $6(15.4)$ & $1.51(0.59-3.87)$ & \\
\hline $5-8$ & $31(13.7)$ & $1.32(0.78-2.23)$ & \\
\hline$\geq 9$ & $32(10.8)$ & 1.00 & \\
\hline Family income (minimum wage) & & & 0.44 \\
\hline$<1$ & $10(11.2)$ & $1.06(0.36-3.08)$ & \\
\hline $1-3$ & 40 (11.6) & $1.09(0.44-2.70)$ & \\
\hline 4-5 & $13(18.3)$ & $1.87(0.66-5.28)$ & \\
\hline$>5$ & $6(10.7)$ & 1.00 & \\
\hline Marital status & & & 0.37 \\
\hline Married/With partner & $55(11.7)$ & 1.00 & \\
\hline Unmarried & $14(15.1)$ & $1.33(0.71-2.52)$ & \\
\hline Smoking during index pregnancy & & & 0.41 \\
\hline No & $56(11.8)$ & 1.00 & \\
\hline Yes & $13(14.9)$ & $1.31(0.69-2.52)$ & \\
\hline Alcohol use in previous month & & & 0.41 \\
\hline No & $56(11.8)$ & 1.00 & \\
\hline Yes & $13(14.9)$ & $1.31(0.68-2.52)$ & \\
\hline History of preterm birth & & & 0.10 \\
\hline No & $27(12.3)$ & $3.45(0.79-14.99)$ & \\
\hline Yes & $2(3.9)$ & 1.00 & \\
\hline Number of prenatal care visits & & & 0.81 \\
\hline$\leq 3$ & $10(13.2)$ & $1.09(0.53-2.24)$ & \\
\hline$\geq 4$ & $59(12.2)$ & 1.00 & \\
\hline Antenatal care at SUS & & & 0.20 \\
\hline No & $7(7.8)$ & 1.00 & \\
\hline Yes & $58(12.7)$ & $1.72(0.76-3.90)$ & \\
\hline
\end{tabular}

95\%Cl: 95\% confidence interval; OR: odds ratio; SUS: Brazilian Unified National Health System.

* $\mathrm{p}$-value for the Wald test.

Because of the limited statistical power for detecting associations with risk factors, we only presented descriptive, exploratory results of the associations between $C$. trachomatis prevalence and socio-demographic and health care-related factors.

Since access to prenatal care is a reality for the majority of women in Brazil, the possibilities of accessing both women and their partners during the pregnancy are much greater than in some other settings. Attempting to diagnose and treat this infection after delivery, as done in our study, limits the possibility of success.

The new clinical protocol of the Brazilian Ministry of Health for treatment of sexually transmitted infections includes the recommendation for C. trachomatis screening 20 , when available, for pregnant 
women below 25 years of age, but the test is not currently covered by the SUS and is not part of routine prenatal care recommended by the Brazilian Ministry of Health 21.

In Brazil, studies in different populations and with different methodologies have reported high prevalence of C. trachomatis infection, so the subject is already established as a public health problem. Further measures by public health authorities are needed to make C. trachomatis screening available for this group with high prevalence of the infection.

\section{Contributors}

M. F. Silveira, I. K. T. Sclowitz, L. G. Entiauspe, M. A. Mesenburg, D. Stauffert, G. L. O. Bicca, C. Pieniz and A. B. Manta prticipated in the conception, project, data analysis and interpretation, writing of the article and relevant critical revision of the intellectual content, and approval of the final version for publication.

\section{Acknowledgments}

The authors wish to thank Becton Dickinson and Company (BDTM) for donating the material used in the Chlamydia trachomatis/Neisseria gonorrhoeae tests. 


\section{References}

1. Paavonen J, Eggert-Kruse W. Chlamydia trachomatis: impact on human reproduction. Hum Reprod Update 1999; 5:433-47.

2. Amaral MG, Kulay Junior L, Granato C, Novo NF, Belfort Junior R. Infecção por C. trachomatis e fatores de risco em gestantes. Rev Assoc Med Bras 1995; 41:193-6.

3. Miranda AE, Szwarcwald CL, Peres RL, PageShafer K. Prevalence and risk behaviors for chlamydial infection in a population-based study of female adolescents in Brazil. Sex Transm Dis 2004; 31:542-6.

4. Pinto VM, Szwarcwald CL, Baroni C, Stringari LL, Inocêncio LA, Miranda AE. Chlamydia trachomatis prevalence and risk behaviors in parturient women aged 15 to 24 in Brazil. Sex Transm Dis 2011; 38:957-61.

5. Silveira MF, Erbelding EJ, Ghanem KG, Johnson HL, Burke AE, Zenilman JM. Risk of Chlamydia trachomatis infection during pregnancy: effectiveness of guidelines-based screening in identifying cases. Int J STD AIDS 2010; 21:367-70.

6. Ministério da Saúde. Manual de controle das doenças sexualmente transmissíveis. 4a Ed. Brasília: Ministério da Saúde; 2005.

7. Guimarães EM, Guimarães MD, Vieira MA, Bontempo NM, Seixas MSS, Garcia MSD, et al. Lack of utility of risk score and gynecological examination for screening for sexually transmitted infections in sexually active adolescents. BMC Medicine 2009; 7:8

8. Bettiol H, Rona RJ, Chinn S, Goldani M, Barbieri MA. Factors associated with preterm births in Southeast Brazil: a comparison of two birth cohorts born 15 years apart. Paediat Perinat Epidemiol 2000; 14:30-8

9. Barros FC, Victora CG, Barros AJ, Santos IS, Albernaz E, Matijasevich A, et al. The challenge of reducing neonatal mortality in middle-income countries: findings from three Brazilian birth cohorts in 1982, 1993, and 2004. Lancet 2005; 365:847-54.

10. Silveira MF, Santos IS, Barros AJD, Matijasevich A, Barros FC, Victora CG. Aumento da prematuridade no Brasil: uma revisão de estudos de base populacional. Rev Saúde Pública 2008; 42:957-64.

11. Lamont RF, Sawant SR. Infection in the prediction and antibiotics in the prevention of spontaneous preterm labour and preterm birth. Minerva Ginecol 2005; 57:423-33.

12. Lamont RF. Infection in the prediction and antibiotics in the prevention of spontaneous preterm labour and preterm birth. BJOG 2003; 110 Suppl 20:71-5.

13. McDonald HM, Brocklehurst P, Gordon A. Antibiotics for treating bacterial vaginosis in pregnancy. Cochrane Database Syst Rev 2013; (1):CD000262.
14. Rekart ML, Gilbert M, Meza R, Kim PH, Chang M, Money DM, et al. Chlamydia public health programs and the epidemiology of pelvic inflammatory disease and ectopic pregnancy. J Infect Dis 2013; 207:30-8.

15. Low N, Egger M. What should we do about screening for genital chlamydia? Int J Epidemiol 2002; 31:891-3.

16. Department of Health, Government of Western Australia. Clinical practice guideline: chlamydia in pregnancy. East Perth: Department of Health, Government of Western Australia; 2008.

17. Catchpole M, Robinson A, Temple A. Chlamydia screening in the United Kingdom. Sex Transm Infect 2003; 79:3-4.

18. Scottish Intercollegiate Guidelines Network. Management of genital Chlamydia trachomatis infection: a national clinical guideline. Edinburgh: Scottish Intercollegiate Guidelines Network; 2009.

19. Watson EJ, Templeton A, Russell I, Paavonen J, Mardh PA, Stary A, et al. The accuracy and efficacy of screening tests for Chlamydia trachomatis: a systematic review. J Med Microbiol 2002; 51:1021-31.

20. Secretaria de Ciência, Tecnologia e Insumos Estratégicos, Ministério da Saúde. Protocolo clínico e diretrizes terapêuticas de infecções sexualmente transmissíveis. Brasília: Ministério da Saúde; 2015

21. Ministério da Saúde. Assistência pré-natal: manual técnico. 3a Ed. Brasília: Ministério da Saúde; 2000.

22. Santos IS, Barros AJ, Matijasevich A, Domingues MR, Barros FC, Victora CG. Cohort profile: the 2004 Pelotas (Brazil) birth cohort study. Int J Epidemiol 2011; 40:1461-8.

23. Workowski KA, Berman S; Centers for Disease Control and Prevention. Sexually transmitted diseases treatment guidelines, 2010. MMWR Recomm Rep 2010; 59:1-110.

24. U.S. Preventive Services Task Force. Screening for chlamydial infection: U.S. Preventive Services Task Force recommendation statement. Ann Intern Med 2007; 147:128-34.

25. Tao G, Hoover KW, Leichliter JS, Peterman TA, Kent CK. Self-reported Chlamydia testing rates of sexually active women aged 15-25 years in the United States, 2006-2008. Sex Transm Dis 2012; 39:605-7.

26. Fine D, Fanfair RN, Salomon S, Nakatsukasa-Ono W, Markowitz L. Chlamydia trachomatis (CT) in older female family planning (FP) clinic clients: assessing effectiveness and efficiency of screening algorithms based on USPHS region $\mathrm{X}$ infertility prevention project (IPP) records, 2009-2011. Sex Transm Dis 2014; 41 Suppl 1:S7-8. 


\section{Resumo}

Este estudo estimou a prevalência de Chlamydia trachomatis durante a gestação entre mulheres de até 29 anos e investigou fatores de risco sociodemográficos, como idade materna, estado civil, escolaridade materna e renda familiar, para a infecção na cidade de Pelotas, Rio Grande do Sul, Brasil. Infecção por C. trachomatis foi diagnosticada por PCR utilizando BD ProbeTecTM CT/GC Amplified DNA Assay system. Dados sociodemográficos, comportamentais e reprodutivos foram coletados através de questionários estruturados. Todas as coletas foram realizadas por estudantes de medicina treinados. Amostra probabilística estratificada de quatro maternidades da cidade foi estudada. A amostra constou de 562 gestantes e a prevalência de infecção por $\mathrm{C}$. trachomatis foi de 12,3\% (IC95\%: 9, 6-15,0). Não foi identificada associação significativa entre infecção por C. trachomatis $e$ as variáveis investigadas, incluindo desfechos obstétricos como parto pretermo. Nossos achados de baixa adesão ao tratamento, de apenas 43\% entre as mulheres e de 9,7\% entre os parceiros, associados a alta prevalência, reforçam a necessidade de implementar rastreamento de rotina para C. trachomatis durante a assistência pré-natal. A tentativa de diagnosticar e tratar esta infecção depois do parto, como feito neste estudo, limita a possibilidade de sucesso.

Chlamydia; Infecções do Sistema Genital; Nascimento Prematuro; Doenças Sexualmente Transmissiveis

\section{Resumen}

Este estudio estimó la prevalencia de Chlamydia trachomatis durante la gestación, entre mujeres de hasta 29 años, e investigó factores de riesgo sociodemográficos como: edad materna, estado civil, escolaridad materna y renta familiar, para esta infección en la ciudad de Pelotas, Rio Grande do Sul, Brasil. La infección por C. trachomatis fue diagnosticada mediante PCR, utilizando BD ProbeTecTM CT/GC Amplified DNA Assay system. Los datos sociodemográficos, comportamentales $y$ reproductivos se recogieron a través de cuestionarios estructurados. Todas las recogidas de datos se realizaron por parte de estudiantes de medicina entrenados. Se estudió la muestra probabilística estratificada de cuatro maternidades de la ciudad. La muestra constó de 562 gestantes y la prevalencia de infección por $\mathrm{C}$. trachomatis fue de un 12,3\% (IC95\%: 9,6-15,0). No se identificó una asociación significativa entre infección por C. trachomatis y las variables investigadas, incluyendo desenlaces obstétricos como el parto pretérmino. Nuestros hallazgos de baja adhesión al tratamiento, solamente un $43 \%$ entre las mujeres y un 9,7\% entre los compañeros, asociados a la alta prevalencia, refuerzan la necesidad de implementar una exploración de rutina para C. trachomatis durante la asistencia prenatal. La tentativa de diagnosticar y tratar esta infección después del parto, como se realizó en este estudio, limita la posibilidad de éxito.

Chlamydia; Infecciones del Sistema Genital;

Nacimiento Prematuro; Enfermedades de

Transmisión Sexual
Submitted on 27/Apr/2015

Final version resubmitted on $04 / \mathrm{Feb} / 2016$

Approved on 11/Mar/2016 